\title{
Price Strategy, Market Orientation, and Business Performance in the Hotel Industry
}

Carlos A. F. Sampaio, Instituto Politécnico de Castelo Branco, Portugal \& NECE, Universidade da Beira Interior, Portugal (iD) https://orcid.org/0000-0002-5249-7798

Ricardo Gouveia Rodrigues, NECE, Universidade da Beira Interior, Portugal

iD https://orcid.org/0000-0001-6382-5147

José M. Hernández-Mogollón, Universidad de Extremadura, Spain

(iD https://orcid.org/0000-0002-5515-8142

\begin{abstract}
This study seeks to study the relationship between market orientation and business performance and to evaluate the mediating effect of adopting a low-price strategy in this relationship in the hotel industry. A sample from the Spanish and Portuguese hotel industry is used. Results show that the effect of market orientation on business performance is positive and direct. On the other hand, the results do not confirm the mediating effect of a strategy based on low-price in the strength of this relationship. Moreover, results indicate that a price strategy based on low-price is negatively related to hotel business performance.
\end{abstract}

\section{KEYWORDS}

Business Performance, Hospitality Industry, Hotel Industry, Market Orientation, Mediating Effect, PLS, Pricing Strategy, Tourism Marketing

\section{INTRODUCTION}

Market orientation literature faced a faster development in the 1990s when Kohli and Jaworski (1990) and Narver and Slater (1990) established the foundations for the following research on this subject. During this period, several market orientation scales were developed (Deshpandé \& Farley, 1998; Deshpande, Farley, \& Webster, 1993; Jaworski \& Kohli, 1993; Kohli, Jaworski, \& Kumar, 1993; Narver \& Slater, 1990; Ruekert, 1992), although, MKTOR scale (Narver \& Slater, 1990) and Jaworski and Kohli (1993) scale, or its reduced version, MARKOR scale (Kohli et al., 1993) established the cornerstone of the market orientation research.

Furthermore, research on market orientation was mainly directed to the industrial and consumer goods sectors (Gray, Matear, \& Matheson, 2002; Quintana-Déniz, Beerli-Palacio, \& MartínSantana, 2007; Sin, Tse, Heung, \& Yim, 2005). Nevertheless, in recent years, several studies testing the relationship between market orientation and business performance on the hotel industry were 
carried out (Bazazo, Alansari, Alquraan, Alzgaybh, \& Masa'deh, 2017; Hinson, Abdul-Hamid, \& Osabutey, 2017; Jogaratnam, 2017; Polo-Peña, Frías-Jamilena, \& Rodrigues-Molina, 2012; Sampaio, Hernández-Mogollón, \& Rodrigues, 2019; Wang, Chen, \& Chen, 2012) yet, there is a shortage of market orientation research on the hotel industry with a transnational scope.

The tourism industry depends on the hotels' ability to provide accommodation and is recognized as a key factor influencing a country or region's economic potential, employment, and social and environmental variables. This is particularly the case of Spain and Portugal. According to the Eurostat (2019b), Spain, in 2017, was the most common tourist destination in the EU for non-residents (people traveling outside their country), with 306 million nights spent in tourist accommodation establishments, or $20.0 \%$ of the EU-28 total. As for Portugal, the total contribution of Travel \& Tourism to GDP was EUR33.5bn, 17.3\% of GDP in 2017, and was forecasted to rise to EUR44.7bn, 20.5\% of GDP in 2028 (World Travel and Tourism Council, 2018).

Nevertheless, hotel companies face several challenges, such as the high fixed costs and floating demand that puts pressure on hotel business performance. On the other hand, travelers tend to use online travel agencies to search and book hotel rooms (Toh, DeKay, \& Raven, 2011) and online search engines (such as booking.com, expedia.com) experienced significant growth on the accommodation reservation services (Booking Holdings Inc., 2019; Expedia Group, 2019), retaining a booking commission and pressuring further the hotels gross margin.

Moreover, according to Liu and Zhang (2014), channel related factors have a positive effect on customers purchase intention and product price and product review are among the most important factors driving customers to a booking channel and their priority. On the other hand, price is key factor in the selection of accommodation (Lockyer, 2005) and hotels change prices according to an inter-temporal structure of the trend primarily depending on the type of customer (leisure or business) and the star rating (Abrate, Fraquelli, \& Viglia, 2012).

Furthermore, the two most common strategies used by hotel managers are low-cost leadership through price discounting and developing customer loyalty by providing unique benefits to customers (Kandampully \& Suhartanto, 2000), which customers are aware through the available information about product price and product review in the online booking engines.

Therefore, there is a significant positive relationship between perceived price and the surrogates for perceived quality (staff and condition) (Bojanic, 1996). Price is what is given up or sacrificed to obtain a product (Zeithaml, 1988) and market orientation seeks to provide superior value to customers (Narver \& Slater, 1990), combining price and service quality. Thus, this work has two main objectives. First, to evaluate the nature of the relationship between market orientation and business performance, and second, to access the mediating effects of a strategy based on a low-price on the relationship between market orientation and business performance in the hotel industry.

To accomplish the objectives defined above, a literature analysis is conducted, and the model hypotheses are formulated. Next, the methodologic procedures used in this research are described, and the obtained results are presented. Finally, some conclusions about this research are proposed.

\section{LITERATURE REVIEW AND HYPOTHESIS DEVELOPMENT}

\section{Market Orientation, Business Performance and Hotel Industry}

Despite the early definitions of market orientation in the 1950s, the advent of the 1980s brought a rediscovery of the marketing concept (Webster, 1988), and a relative shifting from marketing oriented as the implementation of the marketing concept, to market orientation defined as the set of processes touching every company departments targeting the market (Shapiro, 1988). Nevertheless, the 1990s shaped the current state of market orientation research. Narver and Slater (1990) and Kohli and Jaworski (1990) established the framework for the following work about this issue. 
According to Narver and Salter (1990), market orientation is seen as a concept built on three behavioural components: customer orientation, competitor orientation and inter-functional coordination, whereas Kohli and Jaworski (1990) defined market orientation as a concept consisting in three activities: intelligence generation, intelligence dissemination and responsiveness.

From a theoretical point of view, two main approaches were established. Market orientation was seen from a cultural perspective or from a managerial focus perspective (Lafferty \& Hult, 2001). Shapiro (1988), Kohli and Jaworski (1990), and Ruekert (1992) exemplified a more managerial focus, whereas Narver and Slater (1990), and Deshpandé et al. (1993) studies represented market orientation as a kind of organisational culture.

Notwithstanding the theoretical developments, market orientation was widely reported as having a positive effect on business performance (Chang, Franke, Butler, Musgrove, \& Ellinger, 2014; Haugland, Myrtveit, \& Nygaard, 2007; Kara, Spillan, \& Deshields, 2005; Kirca, Jayachandran, \& Bearden, 2005; Lee, Kim, Seo, \& Hight, 2015; Liao, Chang, Wu, \& Katrichis, 2011; Nwokah, 2008; Wang et al., 2012).

For several years, the hospitality sector has been overlooked in the development of the existent market orientation measurement models. The scales used to measure market orientation in the hotel industry are usually based on MARKOR (Kohli et al., 1993) and MKTOR (Narver \& Slater, 1990) scales, or some kind of adaptation to these models. Nevertheless, recently, some proposals emerged to improve these models and adapt them to the hotel sector (e.g., Campo, Díaz, \& Yagüe, 2014; Polo-Peña et al., 2012; Wang et al., 2012).

Moreover, market orientation studies on hospitality sector were carried out more frequently in the 2000s, showing that market orientation is positively related with hotel business performance (e.g., Agarwal, Erramilli, \& Dev, 2003; Campo et al., 2014; Gray, Matear, \& Matheson, 2000; Jogaratnam, 2017; Kasim, Ekinci, Altinay, \& Hussain, 2018; Polo-Peña et al., 2012; Sampaio, Rodrigues, \& Hernández-Mogollón, 2019; Sin et al., 2005; Vega-Vázquez, Cossío-Silva, \& Revilla-Camacho, 2016).

Therefore, the proposed model states that market orientation enhances a business knowledge on how to provide superior value to customers, thus, increasing business performance. This is done by means of gathering intelligence on customers' needs and preferences. The staff plays a critical role, analysing exogenous factors that influence those needs and preferences and balancing it with a focus on competition (Kohli \& Jaworski, 1990) and other market structure issues.

Thus, the following hypothesis was formulated:

H1: There is a positive direct effect between market orientation and business performance.

\section{Price Strategy, Market Orientation and Business Performance}

Guests accommodation selection is an interesting research stream and has been intensively analysed in literature and, for the guest, the created value is a critical point in the choosing process, yet, there is some sort of divergence between the guest point of view when choosing a hotel and the hotels managers thoughts on the drivers of the guests decisions (Lockyer, 2000, 2002, 2005).

Lewis (1987) found five cases of critical factors for guests' expectations: cleanliness, the comfort of bed; quick check-in/check-out; staff friendliness; and quiet. Conversely, according to Lewis hotels management does not realize the importance of these factors.

Similarly, Dolnicar and Otter, (2003), found several factors influencing hotels occupancy. Among them, convenient location, service quality, reputation, friendliness of staff, price, and room cleanliness, were the most important ones. Furthermore, location and accessibility, staff performance, and room quality were found to be the core determinants of customer satisfaction (Xu \& Li, 2016) and the length of stay affects costumers expected discount (Schwartz, Riasi, \& Liu, 2018).

According to Lockyer $(2000,2002,2005)$, cleanliness was also found as an essential factor in the guests' accommodation decision. Interestingly, the Lockyer (2005) research conducted a quantitative 
and qualitative study. When asking hotels guests about the factors driving their accommodation selection, cleanliness was found to be the most critical factor for accommodation selection by the quantitative research. However, when asking the participants to write down the three most important factors when selecting hotel or motel accommodation, the price was listed as the first most crucial factor.

Furthermore, according to Lockyer (2002), hotel managers see guest accommodation selection depending on the relationship between facilities, location, price and staff. Conversely, hotels guests' accommodation decision depends on a close relation between friendly, location, service, and restaurant. Moreover, price level seems to have an effect on consumer expectations (Bojanic, 1996) and firms may add value by improving perceived quality or lowering perceived price (Kashyap \& Bojanic, 2000).

Hotel industry, as a service industry faces several issues related to the intangible nature of the business. Furthermore, hotels demand is not constant, and hotels tend to adapt their prices according to the demand. For instance, according to Abrate et al. (2012), the hotels' prices vary according to the weekday (mid-week day or weekend day) and according to the type of guest (business people or leisure customer). Furthermore, these authors found that, in some cases, prices tend to get lower, close to a guest check-in date, as the hotel looks to fill empty rooms.

From the consumer's perspective, price is what is given up or sacrificed to obtain a product (Zeithaml, 1988), and people evaluate products on the basis of their perceptions of price, quality and value, rather than objective attributes such as actual prices or actual quality. Therefore "expressions of value can be captured in one overall definition: perceived value is the consumer's overall assessment of the utility of a product based on perceptions of what is received and what is given" (Zeithaml, 1988 , p. 14). Furthermore, customer price perception is positively related to customer satisfaction and with customer consumption emotions (Ali, Amin, \& Ryu, 2016) and plays a key role in providing exceptional customers value (Amin, Yahya, Ismayatim, Nasharuddin, \& Kassim, 2013).

Market orientation enables value creation to customers and continuous business performance improvement (Narver \& Slater, 1990) and allows a unifying objective to individuals and departments, conducting to superior business performance. It also produces a sense of belonging in the workforce to the organization, in which the central goal is to satisfy the customer, conducting to a compromise with the efforts of clients satisfaction (Kohli \& Jaworski, 1990), and consequently improving business performance.

On the other hand, the main goal for a company existence is customer satisfaction, and it is the customer who determines what the business is (Drucker, 1954). Thus, satisfying clients' needs is generally recognized as important to managers because it is assumed to be a significant determinant of repeat sales, positive word-of-mouth, and consumer loyalty (Bearden \& Teel, 1983). Satisfaction is also essential to clients, once it represents the positive effect or the reward for satisfying needs (Day \& Landon, 1977). Furthermore, consumer satisfaction level depends primarily on two factors: expected service and perceived service (Grönroos, 1984). Therefore, the expected service and the perceived service depends on what customer values for a given price.

Service provided by hotels is basically immaterial and can be characterized as an activity where production and consumption to a considerable extent take place simultaneously (Grönroos, 1984). Therefore, service companies, as hotels, depended strongly on humans' interactions to satisfy clients' needs. The effective delivery of services is dependent upon the attention and attitudes of staff as well as their performance (Mullins, 1993). Providing superior value to clients by means of a marketoriented organization is a complex process that requires considerable expenditure of money and time (Slater \& Narver, 1994), as well as a commitment of resources, and is only useful if the benefits it affords exceed the cost of those resources (Kohli and Jaworski, 1990).

Therefore, market orientation increases the underlying cost of the service, having hence a negative effect on a low-price strategy, leading to the following hypothesis:

H2: There is a negative direct effect between market orientation and a hotel low-price strategy. 
For a stable accommodation demand, hotels decisions about the pricing strategy will affect the gross margin. Yet, hotels face high fixed costs, a fixed rate of supply, but a fluctuating, seasonal and often unpredictable demand (Mullins, 1993). Furthermore, the hotels' prices are not stable, it vary according to the weekday (mid-week day or weekend day) and according to the type of guest (business people or leisure customer) (Abrate et al., 2012) which, pressures the gross margin and consequently business performance.

On the other hand, providing superior service quality to customers leads to a higher commitment to the hotel brand (Tavitiyaman, Qu, \& Zhang, 2011), leading also to higher costs. Furthermore, customers are increasingly ware of hotels offers and online reviews acquired increasing importance in the reputational arena, implying that further effort should be made to satisfy and improve customers' experiences and expectations over time (Abrate \& Viglia, 2016), in which the accommodation price plays a relevant role (Ali et al., 2016; Dolnicar \& Otter, 2003; Schwartz et al., 2018). Nevertheless, a hotel strategy based on a low-price should have a negative effect on hotel business performance. The expected service and the perceived service are closely related to what the customer gives or sacrifices to have it and a low-price strategy implies lower margins to the hotels and one of the main reasons for company existence is to be profitable.

Consequently, companies pursuing a low-price strategy will suffer from low margins, implying that the relationship between a low-price strategy and business performance would be negative, leading to the following hypothesis:

H3: There is a negative direct effect between a hotel low-price strategy and hotel business performance.

Finally, market orientation is recognised to provide superior value to customers, although, its characteristics are usually related to a superior price premium to the supplier. Moreover, developing a market-oriented organization is a complex process that requires considerable expenditure of money and time (Slater \& Narver, 1994) and market orientation is positively related with business performance (Jogaratnam, 2017; Kasim et al., 2018; Sampaio, Rodrigues, et al., 2019; Vega-Vázquez et al., 2016).

Consequently, market orientation should be positively associated with hotel business performance (H1), negatively associated with a hotel low-price strategy (H2) and the low-price strategy, negatively associated with hotel business performance (H3). This issue implies that the mediating effect of a hotel strategy based on low prices on the relationship between market orientation and business performance should be assessed.

Therefore, the following hypothesis was formulated:

H4: The relationship between market orientation and business performance is mediated through a hotel low-price strategy.

\section{METHODS}

As it was stated in the introduction section, the purpose of this work is to analyse the relationship between market orientation and business performance and to evaluate the mediating effects of a lowprice strategy on this relationship. To perform this analysis, a survey was sent to the managers of a sample of Spanish and Portuguese hotels.

\section{Measurement Scales}

Former market orientation measurement scales, namely the MARKOR scale and the MKTOR scale face several problems and raised some criticisms about its validity and reliability (Farrell, 2002; Farrell \& Oczkowski, 1997; Gauzente, 1999; Pelham, 1993; Siguaw, Brown, \& Widing II, 1993), therefore, the market orientation (MO) construct was measured using a scale developed based on a 
literature review and following Churchill's (1979), Webb (2002) and Nunnaly and Bernstein (1994) guidelines on scale development.

Market orientation proposed scale items were sent by an online survey to a group of academic marketing experts from Western Europe countries to assess its content validity. The obtained responses gave to the authors strong evidence that the proposed market orientation measurement model holds content validity. The final market orientation measurement scale is considered a multidimensional construct and it was based on the three dimensions of intelligence generation (IG), intelligence dissemination (ID) and a coordinated response (CR) about three domains: client, competition and market structure. Each one of the three dimensions (intelligence generation, intelligence dissemination and a coordinated response) having seven items.

Low-price strategy $(\mathrm{P})$ was assessed using a judgemental measurement scale that comprises three items, based on (Zhou, Brown, \& Dev, 2009). Hotel managers were asked to provide their perception of their company price positioning strategy.

Business performance (BP) was measured using a judgmental measurement scale that comprises five indicators, partially based on Powell (1995) total performance scale, measuring profitability, sales growth and occupancy rate.

Survey items were assessed with a 1-7 Likert-type scale in which one represents strongly disagree, and seven represents strongly agree and aggregates three scales to measure market orientation, lowprice strategy and business performance.

\section{Sample}

Data used in this research were collected using an online survey sent to the managers of a sample of 9,217 hotels around Spain and Portugal. The statistical population was composed by the set of hotel companies from Spain and Portugal.

Hotel companies are defined as tourist accommodation establishments. A local kind-of-activity unit providing a paid service (although the price might be partially or fully subsidised) and short-term or short-stay accommodation services (Eurostat, 2019a).

Hotel contacts were obtained in the government tourism departments and the Spanish and Portuguese yellow pages service.

Data collection was conducted between October 2013 and January 2014. All valid questionnaires were answered by the hotels' directors, marketing department directors or direction assistants.

A total of 232 valid surveys were obtained, representing a response rate of $2.5 \%$, among them, 17 (7.33\%) were one-star hotels, $33(14.22 \%)$ were two-star hotels, $79(34.05 \%)$ were three-star hotels, $81(34.92 \%)$ were four-star hotels and $22(9.48 \%)$ were five-star hotels. Regarding the industrial structure, $41(17,7 \%)$ hotels were part of a hotel chain, and $191(82,3 \%)$ were independent hotels. Furthermore, 127 (54,74\%) responses were obtained from Portugal and 105 (45,26\%) from Spain.

\section{RESULTS}

This research used a component-based structural equation modelling (PLS), and the SmartPLS 3.0 (Ringle, Wende, \& Becker, 2015) software was used to compute data.

Data analysis was conducted in two steps. Firstly, the measurement models were evaluated, following Hair et al. (2017). Indicator reliability, model purification and internal consistency reliability through the composite reliability indicator were assessed. Convergent validity was assessed throughout the average variance extracted (AVE) that should be higher than 0.50 .

The discriminant validity was evaluated using the heterotrait-monotrait ratio of correlations (HTMT) criterion (Henseler, Ringle, \& Sarstedt, 2015) and the square root of the AVE of each construct that should be higher than its highest correlation with any other construct (Fornell \& Larker, 1981).

Secondly, the proposed model was evaluated, and the specific hypotheses and the general structural model were assessed. 


\section{Assessing the Measurement Models}

Following Jarvis, MacKenzie, and Podsakoff (2003) guidelines to determine whether a construct is formative or reflexive, the latter approach was used. Moreover, the conceptual model comprises second order constructs. A two-step analysis was conducted (Wright, Campbell, Thatcher, \& Roberts, 2012) to work around this issue. Firstly, first order constructs validity and reliability were evaluated. The measurement models were purified, and construct validity and reliability were achieved. Secondly, data from the first order constructs analysis was computed in a new model and used to evaluate second-order constructs validity and reliability and to assess the structural model.

\section{First Order and Second Order Constructs' Reliability and Validity}

Data were computed and first order constructs outer loadings were evaluated to purify the measurement models. Outer loadings below 0.55 were deleted from the model. According to Chin (1998), standardised loadings should be higher than 0.707 . Nevertheless, this rule of thumb should not be as rigid in the early stages of scale development, and loadings of 0.50 or 0.60 may still be acceptable. Although outer loadings below 0.55 threshold share little in common and are of questionable value in defining the variable (Falk \& Miller, 1992). Therefore, indicators IG7 $=0.451$ and RC3 $=0.296$ were removed from the model. Table 6 shows the measurement models and first and second-order constructs outer loadings.

After the purifying process, the AVE value was evaluated to assess convergent validity. The construct IG with and an AVE of 0,472 (table 1) does not achieve the AVE threshold of 0.50 (Fornell $\&$ Larker, 1981), implying a lack of convergent validity.

To work around this issue, further analysis was conducted. The IG construct single indicators outer loadings were carefully analysed by means of further removing do not decrease content validity (Hair et al., 2017) and the items IG6 $=0.584$ and IG2 $=0.609$ were removed from the model.

Data from the purified model was once again computed and the validity and reliability criteria were finally met (Table 2 and 3). Table 2 shows the reliability results according to the composite reliability indicator, the convergent validity results measured trough the AVE and the discriminant validity according to the Fornell and Larker (1981) criterion, of the first order purified models.

Results from the first order constructs (table 2) show that the AVE values were above 0.50, thereby indicating that convergent validity was established. Furthermore, according to the Fornell and Larker (1981) the discriminant validity was also confirmed (the square root of the AVE of each construct are higher than its highest correlation with any other construct). Results (table 3 ) also show that all the HTMT values are below 0.85 and the inference criterion shows the confidence intervals

Table 1. First-order constructs, convergent validity and reliability indicators

\begin{tabular}{lcc}
\hline \multirow{2}{*}{ Construct } & Reliability & $\begin{array}{c}\text { Convergent } \\
\text { Validity }\end{array}$ \\
\cline { 2 - 3 } & $\begin{array}{l}\text { Composite } \\
\text { Reliability }\end{array}$ & (AVE) \\
\hline BP & 0.919 & 0.695 \\
\hline CR & 0.904 & 0.613 \\
\hline ID & 0.923 & 0.632 \\
\hline IG & 0.841 & $\mathbf{0 . 4 7 2}$ \\
\hline $\mathrm{P}$ & 0.824 & 0.613 \\
\hline
\end{tabular}


Table 2. First order constructs, validity and reliability indicators

\begin{tabular}{cccccccr}
\hline \multirow{2}{*}{ Construct } & \multicolumn{1}{c}{ Reliability } & \multicolumn{1}{c}{$\begin{array}{c}\text { Convergent } \\
\text { Validity }\end{array}$} & \multicolumn{5}{c}{ Discriminant Validity (Fornell \& Larker, 1981) } \\
\cline { 2 - 9 } & $\begin{array}{c}\text { Composite } \\
\text { Reliability }\end{array}$ & (AVE) & \multicolumn{1}{l}{ BP } & CR & ID & IG & P \\
\hline BP & $\mathbf{0 . 9 1 9}$ & $\mathbf{0 . 6 9 5}$ & $\mathbf{0 . 8 3 4}$ & & & & \\
\hline CR & $\mathbf{0 . 9 0 4}$ & $\mathbf{0 . 6 1 3}$ & 0.363 & $\mathbf{0 . 7 8 3}$ & & \\
\hline ID & $\mathbf{0 . 9 2 3}$ & $\mathbf{0 . 6 3 2}$ & 0.397 & 0.69 & $\mathbf{0 . 7 9 5}$ & \\
\hline IG & $\mathbf{0 . 8 2 4}$ & $\mathbf{0 . 5 4 1}$ & 0.379 & 0.576 & 0.661 & $\mathbf{0 . 7 3 5}$ & \\
\hline P & $\mathbf{0 . 8 1 4}$ & $\mathbf{0 . 5 9 9}$ & -0.239 & 0.01 & 0.006 & -0.038 & $\mathbf{0 . 7 7 4}$ \\
\hline
\end{tabular}

\begin{tabular}{cccc}
\hline \multirow{2}{*}{ Path } & HTMT value & \multicolumn{2}{c}{ Confidence Intervals } \\
\cline { 3 - 4 } & & $\mathbf{5 . 0 0 \%}$ & $\mathbf{9 5 . 0 0 \%}$ \\
\hline CR -> BP & 0.409 & 0.275 & 0.535 \\
\hline ID -> BP & 0.442 & 0.327 & 0.548 \\
\hline ID -> CR & 0.771 & 0.689 & 0.845 \\
\hline IG -> BP & 0.471 & 0.33 & 0.604 \\
\hline IG -> CR & 0.717 & 0.614 & 0.813 \\
\hline IG -> ID & 0.811 & 0.735 & 0.882 \\
\hline P -> BP & 0.253 & 0.175 & 0.373 \\
\hline P -> CR & 0.167 & 0.133 & 0.275 \\
\hline P - > ID & 0.108 & 0.096 & 0.212 \\
\hline P -> IG & 0.177 & 0.137 & 0.307 \\
\hline
\end{tabular}

are below the value one, thereby indicating all the HTMT values are significantly different from 1 and that discriminant validity has been established, according to Henseler et al. (2015).

Second order constructs model were computed using data from the first order constructs purified models. Moreover, the second order constructs validity and reliability were evaluated (table 4 and 5). Findings show that the measurement models possess the appropriate convergent and discriminant validity and reliability. The composite reliability values were above 0.70 , the AVE values were above 0.50 , and the square root of the AVE of each construct were higher than its highest correlation with any other construct, the HTMT value is below 0.85 and the inference criterion confidence intervals are significantly different from 1 , establishing, therefore, reliability, convergent validity and discriminant validity, respectively.

\section{Testing the Proposed Model}

Structural equations modelling was used to assess the proposed model, which enables the evaluation of the relationship between the model's variables and to test proposed hypotheses. To evaluate the low-price strategy mediating effects, the Preacher and Hayes (2008) approach was used. This method has been used frequently in empirical studies (Castro \& Roldán, 2013; Vega-Vázquez et al., 2016) and 
Table 4. Second order constructs validity and reliability indicators

\begin{tabular}{lllllll}
\hline & Reliability & \multicolumn{2}{c}{ Convergent validity } & Discriminant validity & & \\
\hline Construct & Composite Reliability & AVE & BP & & MO & P \\
\hline BP & $\mathbf{0 . 9 1 9}$ & $\mathbf{0 . 6 9 5}$ & $\mathbf{0 . 8 3 4}$ & & \\
\hline MO & $\mathbf{0 . 9 0 6}$ & $\mathbf{0 . 7 6 2}$ & 0.435 & $\mathbf{0 . 8 7 3}$ & \\
\hline P & $\mathbf{0 . 8 2 3}$ & $\mathbf{0 . 6 1 1}$ & -0.234 & 0.001 & $\mathbf{0 . 7 8 2}$ \\
\hline
\end{tabular}

Table 5. Second order constructs discriminant validity - HTMT results

\begin{tabular}{cccc}
\hline & \multirow{2}{*}{$\begin{array}{c}\text { HTMT } \\
\text { Path }\end{array}$} & \multicolumn{2}{c}{ Confidence intervals } \\
\cline { 3 - 4 } Value & $\mathbf{5 . 0 0 \%}$ & $\mathbf{9 5 . 0 0 \%}$ \\
\hline $\mathrm{MO}->\mathrm{BP}$ & 0.505 & 0.373 & 0.622 \\
\hline $\mathrm{P}$-> BP & 0.253 & 0.174 & 0.371 \\
\hline $\mathrm{MO}->\mathrm{P}$ & 0.135 & 0.091 & 0.247 \\
\hline
\end{tabular}

the guidelines applied to PLS studies has been settled (Hair et al., 2017; Nitzl, Roldan, \& Cepeda, 2016) in recent years.

The proposed model relationships were analysed. Results (table 7) show a positive and significant direct effect of market orientation on business performance, coefficient path $c^{\prime}=0.436$ (t-value $=$ 6.760), confirming a positive direct relationship between market orientation and business performance (H1). On the other hand, the relationship between market orientation and a hotel low-price strategy $(\mathrm{H} 2)$ was rejected. The coefficient path $\mathrm{a}=0.001$ ( $\mathrm{t}$-value $=0.011)$ does not confirm the significance of this relationship, whereas the coefficient path $b=-0.235$ ( $\mathrm{t}$-value $=3.599$ ) confirms the hypothesis $\mathrm{H} 3$, that there is a negative direct effect between a low-price strategy and hotel business performance.

The next step was to analyse the hypothesised mediated effect of a low-price strategy in the relationship between market orientation and business performance $(\mathrm{H} 4)$. A necessary condition to confirm this premise is the significance of the indirect effect $(a * b)$. Data was computed and shows that the indirect effect $\mathrm{a} * \mathrm{~b}=0,000(\mathrm{t}$-value $=0.012)$.

Despite the result of the total effect, coefficient path $\mathrm{c}=0.438(\mathrm{t}$-value $=6.802)$, has expected, the $\mathrm{H} 4$ was rejected once the significance of the paths $\mathrm{a}$ and $\mathrm{b}$ is condition to confirm a mediating effect of the variable $\mathrm{P}$ on the relationship between the variable MO and the variable BP (Hair, Hult, Ringle, \& Sarstedt, 2013).

Figure 1 (Model 1A and 1B) present the data of the hypothesized coefficient path effects.

Furthermore, predictive accuracy and predictive relevance was computed (table 6). Coefficient of determination ( $R^{2}$ value) is a predictive accuracy measure. $A R^{2}$ of $0.67,0.33$, or 0.19 for endogenous latent variables, can be respectively described as substantial, moderate, or weak (Chin, 1998). Results from the proposed model show an $\mathrm{R}^{2}$ of 0.000 on the $\mathrm{P}$ variable, indicating that the independent variable MO does not contribute to explaining the variance of the endogenous variable $\mathrm{P}$. While the $B P$ variable $R^{2}=0.245$ suggests that the combined effects of the exogenous variables $\mathrm{MO}$ and $\mathrm{P}$ explain $24,5 \%$ of BP endogenous construct. Moreover, the predictive relevance data presented mixed results. For the variable $\mathrm{P}, \mathrm{a} \mathrm{Q}^{2}=-0.3 \%$ indicates that that the exogenous construct $\mathrm{MO}$ does not have predictive relevance on the endogenous construct $\mathrm{P}$. However, the results of the variable BP $\left(\mathrm{Q}^{2}=15,5 \%\right)$ indicates that the exogenous constructs $\mathrm{MO}$ and $\mathrm{P}$ have predictive relevance on the endogenous construct BP. 
Table 6. Measurement models outer loadings

\begin{tabular}{|c|c|c|c|c|c|}
\hline & Measurement models & $\begin{array}{c}\text { First order } \\
\text { constructs } \\
\text { outer } \\
\text { loadings } \\
\end{array}$ & $\begin{array}{c}\text { Second order } \\
\text { constructs } \\
\text { outer loadings }\end{array}$ & $\mathbf{R}^{2}$ & $Q^{2}$ \\
\hline & Market orientation & & & & \\
\hline & Intelligence generation & & 0.855 & & \\
\hline IG1 & We poll our clients to assess our products and services quality. & 0.708 & & & \\
\hline IG2 & We track our competitors' activities and offers at least two times a year. & Dropped & & & \\
\hline IG3 & $\begin{array}{l}\text { We have a gathering information informal procedure (ex: diners, informal } \\
\text { meetings, etc.) about market developments and trends (ex: market structure, etc.) }\end{array}$ & 0.667 & & & \\
\hline IG4 & $\begin{array}{l}\text { Our company is fully committed, when dealing with customers, in gathering } \\
\text { information about their desires and needs, even if they didn't recognize them } \\
\text { yet. }\end{array}$ & 0.793 & & & \\
\hline IG5 & $\begin{array}{l}\text { Our company seeks to obtain quickly market information that could change } \\
\text { clients' perceptions about our products and services. }\end{array}$ & 0.766 & & & \\
\hline IG6 & $\begin{array}{l}\text { Our company seeks to know quickly our competitor's new products and } \\
\text { services, each time they bring them to the market. }\end{array}$ & Dropped & & & \\
\hline IG7 & $\begin{array}{l}\text { People in this firm, other than salespeople, obtain informal information about } \\
\text { our competitors. }\end{array}$ & Dropped & & & \\
\hline & Intelligence dissemination & & 0.903 & & \\
\hline ID1 & Customer information is quickly disseminated to all the firm's departments. & 0.732 & & & \\
\hline ID2 & $\begin{array}{l}\text { In our company, we have a formal information dissemination procedure, among } \\
\text { all the firm's departments, about our clients. }\end{array}$ & 0.66 & & & \\
\hline ID3 & $\begin{array}{l}\text { If a firm's department gets key intelligence about our clients, it spreads the } \\
\text { information quickly to all the other departments. }\end{array}$ & 0.868 & & & \\
\hline ID4 & $\begin{array}{l}\text { Our company usually organizes formal meetings targeted to discuss our } \\
\text { competitors' activities and offers. }\end{array}$ & 0.795 & & & \\
\hline ID5 & $\begin{array}{l}\text { Information about our competitors' advantages known by one of these firm } \\
\text { departments is quickly spread to all the other departments. }\end{array}$ & 0.788 & & & \\
\hline ID6 & $\begin{array}{l}\text { This firm's departments are fully committed to sharing information about } \\
\text { market information and trends affecting our business. }\end{array}$ & 0.841 & & & \\
\hline ID7 & $\begin{array}{l}\text { Information about market structure changes (trends, regulation, etc.), obtained } \\
\text { by one of our firm's departments, spreads quickly to all the other departments. }\end{array}$ & 0.859 & & & \\
\hline & Coordinated response & & 0.86 & & \\
\hline CR1 & $\begin{array}{l}\text { All our company departments are fully committed to respond to our clients' } \\
\text { needs and desires. }\end{array}$ & 0.687 & & & \\
\hline CR2 & $\begin{array}{l}\text { When it is needed to act targeted to clients' needs, all departments in our } \\
\text { company participate. }\end{array}$ & 0.722 & & & \\
\hline CR3 & $\begin{array}{l}\text { Some of this company's departments take more time than it should to respond to } \\
\text { our clients' needs and desires. }\end{array}$ & Dropped & & & \\
\hline CR4 & We always respond to competitive activities from our competitors. & 0.712 & & & \\
\hline CR5 & $\begin{array}{l}\text { Competitive actions from our competitors have a quick, coordinated response } \\
\text { from our company. }\end{array}$ & 0.811 & & & \\
\hline CR6 & $\begin{array}{l}\text { All these company departments respond quickly to changes in market structure } \\
\text { (trends, regulations, etc.) }\end{array}$ & 0.888 & & & \\
\hline CR7 & $\begin{array}{l}\text { Response to market changes is done in a coordinated way by all this firm's } \\
\text { departments. }\end{array}$ & 0.856 & & & \\
\hline & Low-price strategy & & & 0 & -0.003 \\
\hline P1 & Our target market is price sensitive & 0.611 & 0.642 & & \\
\hline P2 & There is great pressure on us to have competitive prices & 0.789 & 0.814 & & \\
\hline P3 & Our customers choose hotels based on prices & 0.896 & 0.87 & & \\
\hline & Business performance & & & 0.245 & 0.155 \\
\hline BP1 & Over the last 3 years, our net income has been outstanding. & 0.876 & 0.876 & & \\
\hline BP2 & Over the last 3 years, our net income has exceeded our competitors. & 0.864 & 0.864 & & \\
\hline BP3 & Over the last 3 years, our sales growth has been outstanding. & 0.867 & 0.867 & & \\
\hline BP4 & Over the last 3 years, our sales growth has exceeded our competitors. & 0.875 & 0.875 & & \\
\hline BP5 & Our occupancy rate is much higher than that of our competitors. & 0.666 & 0.666 & & \\
\hline
\end{tabular}

As for the effect size $f^{2}$, results show a medium effect size of the exogenous construct MO $\left(f^{2}\right.$ $=0.251)$ on the $\mathrm{R}^{2}$ value of the endogenous construct $\mathrm{BP}$, whilst the effect size of the exogenous construct $\mathrm{P}\left(f^{2}=0.073\right)$ on the $\mathrm{R}^{2}$ of the endogenous construct BP indicates a small effect size.

Table 7 summarizes the obtained results of the proposed model.

\section{CONCLUSION}

This research aimed to study the nature of the relationship between market orientation and business performance using a sample obtained in the Spanish and Portuguese hotel industry context and to assess the mediating effects of a strategy based on low-price on this relationship.

To evaluate the proposed model, a two-step analysis was done. The first step was conducted by evaluating the measurement models. First and second order constructs were assessed, and market 
Model 1A
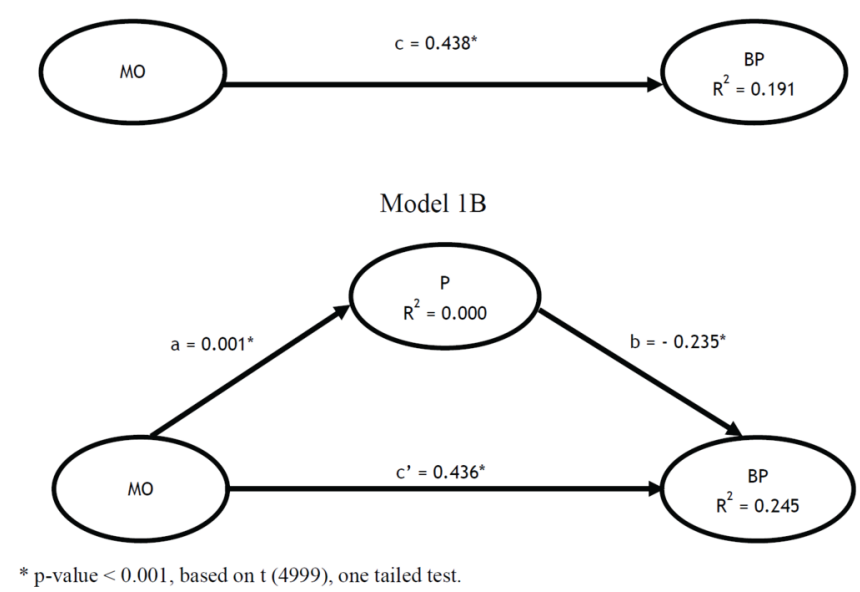

Table 7. Summary, hypotheses and effects

\begin{tabular}{|c|c|c|c|c|c|c|c|c|}
\hline \multirow{3}{*}{ Path } & \multicolumn{2}{|c|}{ Total effect } & \multicolumn{3}{|c|}{ Direct effect } & \multicolumn{2}{|c|}{ Indirect effect } & \\
\hline & \multirow{2}{*}{ Coefficient } & \multirow{2}{*}{ t-value } & \multirow{2}{*}{ Coefficient } & \multirow{2}{*}{ t-value } & \multirow{2}{*}{$\begin{array}{l}\text { Point } \\
\text { estimate }\end{array}$} & \multirow{2}{*}{ t-value } & \multicolumn{2}{|c|}{$\begin{array}{l}\text { Percentile bootstrap } \\
95 \% \text { confidence } \\
\text { interval }\end{array}$} \\
\hline & & & & & & & $\begin{array}{l}\text { Lower } \\
\text { bound }\end{array}$ & $\begin{array}{l}\text { Upper } \\
\text { bound }\end{array}$ \\
\hline $\mathrm{P}->\mathrm{BP}$ & & & $(\mathrm{H} 3)-0.235$ & $3.599 *$ & & & & \\
\hline $\mathrm{MO}->\mathrm{P}$ & & & (H2) 0.001 & $0.011^{*}$ & & & & \\
\hline $\begin{array}{c}\mathrm{MO}->\mathrm{P}-> \\
\text { BP }\end{array}$ & & & & & (H4) 0,000 & $0.012 * *$ & -0.037 & 0.037 \\
\hline $\mathrm{MO}->\mathrm{BP}$ & 0.438 & $6.802 *$ & (H1) 0.436 & $6.760 *$ & & & & \\
\hline
\end{tabular}

orientation, low-price strategy and business performance scales were found to have the appropriate validity and reliability settings. Secondly, the proposed model was evaluated, and the suggested hypotheses were tested.

Results show that the relationship between market orientation and business performance is direct and positive. However, a price strategy based on low-prices has a negative impact on hotel business performance. Furthermore, the results do not confirm a negative relationship between market orientation and a low-price strategy and, consequently, neither the mediating effect of a low-price strategy on the relationship between market orientation and business performance.

The hypothesised positive relationship between market orientation and business performance was confirmed and is well documented in the background literature. Former studies on this subject found a positive relationship between market orientation and business performance (Agarwal et al., 2003; Campo et al., 2014; Gray et al., 2000; Kasim et al., 2018; Polo-Peña et al., 2012; Qu \& Ennew, 2003; Sampaio, Rodrigues, et al., 2019; Sandvik \& Sandvik, 2003; Sin et al., 2005; Vega-Vázquez et al., 2016). On the other hand, the postulated negative relationship between market orientation and a strategy based on low-price was not confirmed. According to the background literature, developing 
a market-oriented organization is a complex process that requires considerable expenditure of money and time (Slater \& Narver, 1994), as well as a commitment of resources, and is only useful if the benefits it affords exceed the cost of those resources (Kohli and Jaworski, 1990). However, results do not confirm a relationship between market orientation and the hotel low-price strategy. This result could be explained because market orientation is the business culture that most effectively and efficiently creates superior value for customers (Slater \& Narver, 2000), and even budget hotels must concentrate on value drivers such as physical product offering, selection of location and staff (Subramanian, Gunasekaran, \& Gao, 2016).

Furthermore, the negative link between a strategy based on low-prices and hotel business performance confirms, as expected, that low-prices should imply a reduced price-premium and consequently lower margins. Moreover, this result also indicates that hotels pursuing a low-price strategy will have a lower occupancy rate and weaker sales growth. Conversely, the mediating role of a price strategy based on low prices was not confirmed. This result is slightly odd, once the price is usually considered a variable that influences customers perceived value (Monroe, 1973; Monroe \& Chapman, 1987; Zeithaml, 1988).

From a theoretical standpoint, this research contributes by taking a step forward on market orientation study in the service sector, particularly in the hospitality industry. Furthermore, the proposed model could be replicated in another context. Additionally, this study expands the knowledge on the relationship between market orientation and business performance in the hospitality industry, particularly by analysing the effect of the hotel price strategy on the relationship between market orientation and business performance and the direct link between the price strategy and the hotels business performance.

This study makes several significant contributions to hotels management. Market orientation by its features of generating intelligence about clients, competition and market structure, intelligence dissemination and coordinated response, positively influences the creation of superior value to clients. Hotel managers would produce a positive effect on business performance by implementing or improving a market orientated organization. Furthermore, service sector companies as hotels depended strongly on humans' interactions to satisfy clients' needs. Therefore, the market orientation positive effects on workforce produce a compromise with the efforts of client satisfaction (Kohli \& Jaworski, 1990) and consequently a positive impact on business performance. Additionally, increasing and maintaining a certain degree of market orientation is a complex process that requires a considerable expenditure of money and time (Slater \& Narver, 1994), requires a commitment of resources, and it is useful only if the benefits exceed the cost of those resources (Kohli \& Jaworski, 1990). Therefore, results show that, despite this view, market orientation could evolve hotels business performance and consequently hotels managers should seek to establish the appropriate degree of market orientation.

Furthermore, the observed negative link between a price strategy based on low-prices and business performance indicates that reducing accommodation prices could have negative consequences on hotels business performance. On the one hand, the adverse effects occur on the present firm profitability, as well as on the potential firm profitability, by negatively influencing the occupancy rate and the sales growth. Therefore, hotel managers should carefully analyse if the short-term benefits of lowering prices, for instance, to fill empty hotel rooms, does not have long-term shortcomings on business profitability, occupancy rate and sales growth.

This work deals with a set of essential questions related to market orientation study in the hotel industry. Despite the enlightening it brought out, it carries several limitations that suggest the need for further research. Firstly, the sample was obtained in the Spanish and Portuguese hotel industry context, and the response rate is quite low. Hotel managing does not leave much time to answer surveys; thus, getting responses from managers is not an easy task. The online survey was found to be the best methodology to work around this issue, despite all the intrinsic cons, namely the low response rate. On the other hand, generalization should be taken with caution once results represent the case of the Spanish and Portuguese hotel industry. 
Furthermore, several hypotheses, despite based on background literature, were not confirmed. These drawbacks represent several opportunities for further research by expanding the analysed context, or testing the hypothesized model in a different cultural environment, to assess if the research findings are replicated or not, or to evaluate if the strategy based on low-price moderates the relationship between market orientation and business performance. 


\section{REFERENCES}

Abrate, G., Fraquelli, G., \& Viglia, G. (2012). Dynamic pricing strategies: Evidence from European hotels. International Journal of Hospitality Management, 31(1), 160-168. doi:10.1016/j.ijhm.2011.06.003

Abrate, G., \& Viglia, G. (2016). Strategic and tactical price decisions in hotel revenue management. Tourism Management, 55, 123-132. doi:10.1016/j.tourman.2016.02.006

Agarwal, S., Erramilli, M. K., \& Dev, C. S. (2003). Market orientation and performance in service firms: Role of innovation. Journal of Services Marketing, 17(1), 68-82. doi:10.1108/08876040310461282

Ali, F., Amin, M., \& Ryu, K. (2016). The Role of Physical Environment, Price Perceptions, and Consumption Emotions in Developing Customer Satisfaction in Chinese Resort Hotels. Journal of Quality Assurance in Hospitality \& Tourism, 17(1), 45-70. doi:10.1080/1528008X.2015.1016595

Amin, M., Yahya, Z., Ismayatim, W. F. A., Nasharuddin, S. Z., \& Kassim, E. (2013). Service Quality Dimension and Customer Satisfaction: An Empirical Study in the Malaysian Hotel Industry. Services Marketing Quarterly, 34(2), 115-125. doi:10.1080/15332969.2013.770665

Bazazo, I., Alansari, I., Alquraan, H., Alzgaybh, Y., \& Masa'deh, R. (2017). The Influence of Total Quality Management, Market Orientation and E-Marketing on Hotel Performance. International Journal of Business Administration, 8(4), 79. doi:10.5430/ijba.v8n4p79

Bearden, W. O., \& Teel, J. E. (1983). Selected Determinats of Consumer Satisfaction and Complaint Reports. JMR, Journal of Marketing Research, XX(1), 21-28. doi:10.1177/002224378302000103

Bojanic, D. C. (1996). Consumer Perceptions of Price, Value and Satisfaction in the Hotel Industry. Journal of Hospitality \& Leisure Marketing, 4(1), 5-22. doi:10.1300/J150v04n01_02

Booking Holdings Inc. (2019). 2018 Annual Report. Retrieved from https://ir.bookingholdings.com/node/24076/ html

Campo, S., Díaz, A. M., \& Yagüe, M. J. (2014). Market orientation in mid-range service, urban hotels: How to apply the MKTOR instrument. International Journal of Hospitality Management, 43, 76-86. doi:10.1016/j. ijhm.2014.08.006

Castro, I., \& Roldán, J. L. (2013). A mediation model between dimensions of social capital. International Business Review, 22(6), 1034-1050. doi:10.1016/j.ibusrev.2013.02.004

Chang, W., Franke, G. R., Butler, T. D., Musgrove, C. F., \& Ellinger, A. E. (2014). Differential Mediating Effects of Radical and Incremental Innovation on Market Orientation-Performance Relationship: A Meta-Analysis. Journal of Marketing Theory and Practice, 22(3), 235-250. doi:10.2753/MTP1069-6679220301

Chin, W. W. (1998). The partial least squares approach to structural equation modeling. In G. Marcoulides (Ed.), A, Modern methods for business research (pp. 295-336). Lawrence Erlbaum Associates. doi:10.1016/j. aap.2008.12.010

Churchill, G. Jr. (1979). A Paradigm for Developing Better Measures of Marketing Constructs. JMR, Journal of Marketing Research, 16(1), 64-73. doi:10.1177/002224377901600110

Day, R. L., \& Landon, L. E. (1977). Toward a Theory of Consumer Complaining Behavior. In A. G. Woodwide, J. N. Sheth, \& P. D. Bennett (Eds.), Consumer and Industrial Buying Behaviour (pp. 425-437). North-Holland: Elsevier Science Ltd.

Deshpandé, R., \& Farley, J. U. (1998). Measuring Market Orientation: Generalization and Synthesis. Journal of Market Focused Management, 2(3), 213-232. doi:10.1023/A:1009719615327

Deshpande, R., Farley, J. U., \& Webster, F. E. Jr. (1993). Corporate Culture, Customer Orientation, and Innovativeness in Japanese Firms - A Quadrad Analysis. Journal of Marketing, 57(1), $23-27$. doi:10.1177/002224299305700102

Dolnicar, S., \& Otter, T. (2003). Which Hotel attributes Matter? A Review of Previous and a Framework for Future Research. In Proceedings of the 9th Annual Conference of the Asia Pacific Tourism Association (APTA) (pp. 176-188). doi:https://ro.uow.edu.au/commpapers/268 
Drucker, P. F. (1954). The Practice of Management. Harper \& Row.

Eurostat. (2019a). Glossary: Tourist accommodation establishment. Retrieved from https://ec.europa.eu/eurostat/ statistics-explained/index.php/Glossary:Tourist_accommodation_establishment

Eurostat. (2019b). Tourism statistics - Statistics Explained. Retrieved from https://ec.europa.eu/eurostat/statisticsexplained/index.php?title=Tourism_statistics

Expedia Group. (2019). Expedia Group Reports Fourth Quarter and Full Year 2018 Results. Retrieved from https://ir.expediagroup.com/static-files/62b0026a-b78f-4f27-b1d2-168f664b80b6

Falk, R. F., \& Miller, N. B. (1992). A Primer for Soft Modeling. University of Akron Press.

Farrell, M. (2002). A Critique of the Development of Alternative Measures of Market Orientation. Marketing Bulletin, 13, 1-13.

Farrell, M. A., \& Oczkowski, E. (1997). An Analysis of the MKTOR and MARKOR Measures of Market Orientation: An Australian Perspective. Marketing Bulletin, 8(Article 3), 30-40.

Fornell, C., \& Larker, D. F. (1981). Evaluating Structural Equation Models with Unobservable Variables and Measurement Error. JMR, Journal of Marketing Research, 18(1), 39-50. doi:10.1177/002224378101800104

Gauzente, C. (1999). Comparing Market Orientation Scales : A Content Analysis. Marketing Bulletin, 10, 76-82.

Gray, B. J., Matear, S. M., \& Matheson, P. K. (2000). Improving the performance of hospitality firms. International Journal of Contemporary Hospitality Management, 12(3), 149-155. doi:10.1108/09596110010320643

Gray, B. J., Matear, S., \& Matheson, P. K. (2002). Improving service firm performance. Journal of Services Marketing, 16(3), 186-200. doi:10.1108/08876040210427191

Grönroos, C. (1984). A Service Quality Model and its Marketing Implications. European Journal of Marketing, 18(4), 36-44. doi:10.1108/EUM0000000004784

Hair, J. F. J., Hult, G. T. M., Ringle, C. M., \& Sarstedt, M. (2013). A Primer on Partial Least Squares Structural Equation Modeling (PLS-SEM). Sage.

Hair, J. F. J., Hult, G. T. M., Ringle, C. M., \& Sarstedt, M. (2017). A Primer On Partial Least Squares Structural Equation Modeling (PLS-SEM) (2nd ed.). Los Angeles: SAGE Publications, Inc.

Haugland, S. A., Myrtveit, I., \& Nygaard, A. (2007). Market orientation and performance in the service industry: A data envelopment analysis. Journal of Business Research, 60(11), 1191-1197. doi:10.1016/j.jbusres.2007.03.005

Henseler, J., Ringle, C. M., \& Sarstedt, M. (2015). A new criterion for assessing discriminant validity in variance-based structural equation modeling. Journal of the Academy of Marketing Science, 43(1), 115-135. doi:10.1007/s11747-014-0403-8

Hinson, R. E., Abdul-Hamid, I. K., \& Osabutey, E. L. C. (2017). Investigating market orientation and positioning in star-rated hotels in Ghana. International Journal of Contemporary Hospitality Management, 29(10), $2629-2646$. doi:10.1108/IJCHM-02-2016-0075

Jarvis, C. B. B., MacKenzie, S. B. B., \& Podsakoff, P. M. M. (2003). A Critical Review of Construct Indicators and Measurement Model Misspecification in Marketing and Consumer Research. The Journal of Consumer Research, 30(September), 199-218. doi:10.1086/376806

Jaworski, B. J., \& Kohli, A. K. (1993). Market Orientation: Antecedents and Consequences. Journal of Marketing, 57(3), 53-70. doi:10.1177/002224299305700304

Jogaratnam, G. (2017). The effect of market orientation, entrepreneurial orientation and human capital on positional advantage: Evidence from the restaurant industry. International Journal of Hospitality Management, 60, 104-113. doi:10.1016/j.ijhm.2016.10.002

Kandampully, J., \& Suhartanto, D. (2000). Customer loyalty in the hotel industry: The role of customer satisfaction and image. International Journal of Contemporary Hospitality Management, 12(6), 346-351. doi:10.1108/09596110010342559 
Kara, A., Spillan, J. E., \& Deshields, O. W. Jr. (2005). The Effect of a Market Orientation on Business Performance : A Study of Small-Sized Service Retailers Using MARKOR Scale. Journal of Small Business Management, 43(2), 105-118. doi:10.1111/j.1540-627x.2005.00128.x

Kashyap, R., \& Bojanic, D. C. (2000). A Structural Analysis of Value, Quality, and Price Perceptions of Business and Leisure Travelers. Journal of Travel Research, 39(1), 45-51. doi:10.1177/004728750003900106

Kasim, A., Ekinci, Y., Altinay, L., \& Hussain, K. (2018). Impact of market orientation, organizational learning and market conditions on small and medium-size hospitality enterprises. Journal of Hospitality Marketing \& Management, 27(7), 855-875. doi:10.1080/19368623.2018.1438955

Kirca, A. H., Jayachandran, S., \& Bearden, W. O. (2005, April). Market Orientation: A Meta-Analytic Review and Assessment of Its Antecedents and Impact on Performance. Journal of Marketing, 69(2), 24-41. doi:10.1509/ jmkg.69.2.24.60761

Kohli, A. K., \& Jaworski, B. J. (1990). Market Orientation: The Construct, Research Propositions and Managerial Implications. Journal of Marketing, 54(April), 1-18. doi:10.1177/002224299005400201

Kohli, A. K., Jaworski, B. J., \& Kumar, A. (1993). MARKOR : A measure of market orientation. JMR, Journal of Marketing Research, 30(4), 467-477. doi:10.1177/002224379303000406

Lafferty, B. A., \& Hult, G. T. M. (2001). A synthesis of contemporary market orientation perspectives. European Journal of Marketing, 35(1/2), 92-109. doi:10.1108/03090560110363364

Lee, Y.-K., Kim, S.-H., Seo, M.-K., \& Hight, S. K. (2015). Market orientation and business performance: Evidence from franchising industry. International Journal of Hospitality Management, 44, 28-37. doi:10.1016/j. ijhm.2014.09.008

Lewis, R. C. (1987). The measurement of gaps in the quality of hotel services. International Journal of Hospitality Management, 6(2), 83-88. doi:10.1016/0278-4319(87)90020-X

Liao, S.-H., Chang, W.-J., Wu, C., \& Katrichis, J. M. (2011). A survey of market orientation research (1995-2008). Industrial Marketing Management, 40(2), 301-310. doi:10.1016/j.indmarman.2010.09.003

Liu, J. N. K., \& Zhang, E. Y. (2014). An investigation of factors affecting customer selection of online hotel booking channels. International Journal of Hospitality Management, 39, 71-83. doi:10.1016/j.ijhm.2014.01.011

Lockyer, T. (2000). A New Zealand Investigation into the Factors Influencing Consumers' Selection of Business Hotel Accommodation. Australian Journal of Hospitality Management, 7(2), 11. https://link.galegroup.com/ apps/doc/A72433599/AONE?u=googlescholar\&sid=AONE\&xid=ae4605a3

Lockyer, T. (2002). Business guests' accommodation selection: The view from both sides. International Journal of Contemporary Hospitality Management, 14(6), 294-300. doi:10.1108/09596110210436832

Lockyer, T. (2005). The perceived importance of price as one hotel selection dimension. Tourism Management, 26(4), 529-537. doi:10.1016/j.tourman.2004.03.009

Monroe, K. B. (1973). Buyers' Subjective Perceptions of Price. JMR, Journal of Marketing Research, 10(1), 70-80. doi:10.2307/3149411

Monroe, V., \& Chapman, J. D. (1987). Framing Effects on Buyers' Subjective Product Evaluations. Advances in Consumer Research. Association for Consumer Research (U. S.).

Mullins, M. J. (1993). The Hotel and the Open System Model of Organizational Analysis. The Service Industries Journal, 13(1), 1-16.

Narver, J. C., \& Slater, S. F. (1990). The Effect of a Market Orientation on Business Profitability. Journal of Marketing, 54(4), 20-35. doi:10.1177/002224299005400403

Nitzl, C., Roldan, J. L., \& Cepeda, G. (2016). Mediation analysis in partial least squares path modeling: Helping researchers discuss more sophisticated models. Industrial Management \& Data Systems, 116(9), 1849-1864. doi:10.1108/IMDS-07-2015-0302

Nunnaly, J. C., \& Bernstein, I. H. (1994). Psychometric Theory (3rd ed.). McGrawHill. 
Nwokah, N. G. (2008). Strategic market orientation and business performance. European Journal of Marketing, 42(3/4), 279-286. doi:10.1108/03090560810852922

Pelham, A. M. (1993). Mediating and moderating influences on the relationship between market orientation and performance. Pennsylvania State University.

Polo-Peña, A. I., Frías-Jamilena, D. M., \& Rodrigues-Molina, M. Á. (2012). Validation of a market orientation adoption scale in rural tourism enterprises. Relationship between the characteristics of the enterprise and extent of market orientation adoption. International Journal of Hospitality Management, 31(1), 139-151. doi:10.1016/j. ijhm.2011.06.005

Powell, T. C. (1995). Total Quality Management as Competitive Advantage: A Review and Empirical Study. Strategic Management Journal, 16(1), 15-37. doi:10.1002/smj.4250160105

Preacher, K., \& Hayes, A. (2008). Asymptotic and resampling strategies for assessing and comparing indirect effects in multiple mediator models. Behavior Research Methods, 40(3), 879-891. doi:10.3758/BRM.40.3.879 PMID:18697684

Qu, R., \& Ennew, C. T. (2003, September). An examination of the consequences of market orientation in China. Journal of Strategic Marketing, 11(3), 201-2014. doi:10.1080/0965254032000133449

Quintana-Déniz, A., Beerli-Palacio, A., \& Martín-Santana, J. (2007). Human resource systems as antecedents of hotel industry market orientation: An empirical study in the Canary Islands, Spain. International Journal of Hospitality Management, 26(4), 854-870. doi:10.1016/j.ijhm.2006.07.007

Ringle, C. M., Wende, S., \& Becker, J.-M. (2015). SmartPLS 3.0. SmartPLS 3. Bönningstedt: SmartPLS. Retrieved from http://www.smartpls.com

Ruekert, R. W. (1992). Developing a market orientation: An organizational strategy perspective. International Journal of Research in Marketing, 9(3), 225-245. doi:10.1016/0167-8116(92)90019-H

Sampaio, C. A. F., Hernández-Mogollón, J. M., \& Rodrigues, R. G. (2019). Assessing the relationship between market orientation and business performance in the hotel industry - the mediating role of service quality. Journal of Knowledge Management, 23(4), 644-663. doi:10.1108/JKM-08-2017-0363

Sampaio, C. A. F., Rodrigues, R. G., \& Hernández-Mogollón, J. M. (2019). The Relationship Between Market Orientation, Customer Loyalty and Business Performance - A Sample from Western Europe Hotel Industry. Tourism and Hospitality Research. Advance online publication. doi:10.1177/1467358419829179

Sandvik, I. L., \& Sandvik, K. (2003). The impact of market orientation on product innovativeness and business performance. International Journal of Research in Marketing, 20(4), 355-376. doi:10.1016/j.jiresmar.2003.02.002

Schwartz, Z., Riasi, A., \& Liu, X. (2018). Gap-alert? Quantity surcharge practices vs. guest expectations. International Journal of Hospitality Management, 73, 108-115. doi:10.1016/j.ijhm.2018.02.010

Shapiro, B. P. (1988). What the Hells Is "Market Oriented"? Harvard Business Review, 66(6), 119-125.

Siguaw, J. A., Brown, G., \& Widing II, R. E. (1993). The influence of the market orientation of the firm on salesforce behaviour and attitudes. School of Business Discussion Papers (Paper 43).

Sin, L. Y. M., Tse, A. C. B., Heung, V. C. S., \& Yim, F. H. K. (2005). An analysis of the relationship between market orientation and business performance in the hotel industry. International Journal of Hospitality Management, 24(4), 555-577. doi:10.1016/j.jhm.2004.11.002

Slater, S. F., \& Narver, J. C. (1994). Does Competitive Environment Moderate the Market Orientation-Performance Relationship? Journal of Marketing, 58(1), 46-55. doi:10.1177/002224299405800104

Slater, S. F., \& Narver, J. C. (2000). The Positive Effect of a Market Orientation on Business Profitability: A Balanced Replication. Journal of Business Research, 48(1), 69-73. doi:10.1016/S0148-2963(98)00077-0

Subramanian, N., Gunasekaran, A., \& Gao, Y. (2016). Innovative service satisfaction and customer promotion behaviour in the Chinese budget hotel: An empirical study. International Journal of Production Economics, 171, 201-210. doi:10.1016/j.ijpe.2015.09.025 
Tavitiyaman, P., Qu, H., \& Zhang, H. Q. (2011). The impact of industry force factors on resource competitive strategies and hotel performance. International Journal of Hospitality Management, 30(3), 648-657. doi:10.1016/j.jjhm.2010.11.010

Toh, R. S., DeKay, C. F., \& Raven, P. (2011). Travel Planning: Searching for and Booking Hotels on the Internet. Cornell Hospitality Quarterly, 52(4), 388-398. doi:10.1177/1938965511418779

Vega-Vázquez, M., Cossío-Silva, F. J., \& Revilla-Camacho, M. Á. (2016). Entrepreneurial orientation-hotel performance: Has market orientation anything to say? Journal of Business Research, 69(11), 5089-5094. doi:10.1016/j.jbusres.2016.04.085

Wang, C.-H., Chen, K.-Y., \& Chen, S.-C. (2012). Total quality management, market orientation and hotel performance: The moderating effects of external environmental factors. International Journal of Hospitality Management, 31(1), 119-129. doi:10.1016/j.ijhm.2011.03.013

Webb, J. R. (2002). Understanding and Designing Marketing Research (2nd ed.). Thomson Learning.

Webster, F. E. J. (1988). The Rediscovery of the Marketing Concept. Business Horizons, (3), 29-39. doi:10.1016/0007-6813(88)90006-7

World Travel and Tourism Council. (2018). Travel \& Tourism Economic Impact 2018 - March 2018. Author.

Wright, R. T., Campbell, D. E., Thatcher, J. B., \& Roberts, N. (2012). Operationalizing Multidimensional Constructs in Structural Equation Modeling : Recommendations for IS Research. Communications of the Association for Information Systems, 30(23), 367-412. doi:10.17705/1CAIS.03023

$\mathrm{Xu}, \mathrm{X} .$, \& Li, Y. (2016). The antecedents of customer satisfaction and dissatisfaction toward various types of hotels: A text mining approach. International Journal of Hospitality Management, 55, 57-69. doi:10.1016/j. ijhm.2016.03.003

Zeithaml, V. A. (1988). Consumer Perceptions of Price, Quality, and Value: A Means-End Model and Synthesis of Evidence. Journal of Marketing, 52(3), 22. doi:10.1177/002224298805200302

Zhou, K. Z., Brown, J. R., \& Dev, C. S. (2009). Market orientation, competitive advantage, and performance: A demand-based perspective. Journal of Business Research, 62(11), 1063-1070. doi:10.1016/j.jbusres.2008.10.001

Carlos Alberto Fernandes Sampaio is an Invited Assistant Professor at Polytechnic Institute of Castelo Branco, researcher, and entrepreneur. He holds a PhD in Business Management. His main research interests are Marketing, Service Quality and Hospitality Industry, and he is author of various papers and Portuguese and international journals and chapters in edited volumes.

Ricardo Gouveia Rodrigues is Professor at University of Beira Interior, and deputy director of the Research Centre NECE-UBI. Holds a PhD in Business. His main research interests are Entrepreneurship and Marketing. Has over 50 international publications, participated in several projects, and coordinated an international project on impact of Entrepreneurship Education.

José Manuel Hernández-Mogollón is a Professor at the Department of Business Management and Sociology, School of Business, Finance and Tourism, University of Extremadura, Spain. He holds a PhD in Economics and Business Management, and he is the author of various papers in Spanish and international journals and chapters in edited volumes. His research interests focus on marketing and tourism management. 